\title{
High School National Examination and its implications for Environmental Science Teaching
}

\author{
Luiz Ricardo Oliveira Santos, Jailton de Jesus Costa e Rosemeri Melo e Souza \\ Universidade Federal de Sergipe, Brasil \\ santos.lro@gmail.com; jailton@ufs.br; rome@ufs.br
}

\begin{abstract}
The National High School Examination (ENEM) is a government policy instituted by the Ministry of Education with the aim of evaluating this teaching stage, also serving as an alternative to access the Higher Education at the main universities of the country, through programs such as the System Unified Selection (SiSU), the University for All Program (ProUni) and Student Funding (FiES). Despite the reformulations it has undergone lately, the exam creates obstacles that can imply teacher autonomy and teaching, compromising the local and integrated approach to environmental themes. The aim of the present study is to discuss the implications of ENEM for the Environmental Science teaching. For this, preliminary bibliographic data such as articles indexed in the CAPES database and documentaries were collected through the analysis of the Human Sciences and Nature Sciences tests applied in 2016, which proved the little approach to local environmental themes in that year, prevailing those of global and the most developed region of the country, contradicting the interdisciplinary proposal of the examination. Thus, it is observed that the ENEM rarely addressed local questions in its tests, and the school should use other pedagogical instruments to improve the effectiveness of Environmental Science Teaching.
\end{abstract}

Keywords: Basic Education; ENEM; Environmental Science Teaching 


\section{INTRODUCTION}

Thinking, feeling, understanding, belonging and acting- are diverse words that can be used as starting point in a discussion about the environment, the term of which can designate various possibilities for analysis or converge to a multiple location that can encompass these interactions, ideologies, and paradigms. Environmental knowledge rises as a need for integration between individual and collective knowledge, thoughts and values, in the face of a socio-environmental crisis. It is observed through the multiplicity of meanings that go beyond the scientific articulation and individual knowledge and has, in its actions, the representations of the ideologies coming from the different groups that do it (LEFF, 2009). Thus, perceive and act is, in a way, belong.

This relationship of belonging can be stimulated through educational actions that intertwine with the experiences of the subjects directly involved with the practices performed, which endow the concepts addressed with intrinsic meanings and tend to approach the values built by society itself, To your place. Not only through physical spaces, delimited by walls, borders, territories or examinations of verification of learning and self-evaluation, the construction of knowledge must be based on feelings, respect and complicity. Among the tests for verifying learning is the National High School Examination (ENEM), which is a government policy instituted in 1998 by the National Institute of Educational Studies and Research Anísio Teixeira (INEP), an agency of the Ministry of Education (MEC), with the objective to evaluate the learning of the students that will conclude this stage of education, besides providing subsidies for the entrance in courses of superior and professional level, through a reference examination (BRAZIL, 1998).

Over the years, this policy was improved and also served as the main instrument of access to public higher education, through the SiSU - Unified Selection System, through the adhesion of several universities that replaced their traditional test by the proof of the ENEM, which required reformulation of its matrix. Likewise, it also allowed access to private higher education by PROUNI - The University for All Program, which aims to grant full and partial scholarships in undergraduate and sequential courses of specific training. Created by the Federal Government in 2004 and institutionalized by Law 11.096 , on January 13, 2005, it offers, on the other hand, exemption from taxes to those institutions that join the program. The Program also has joint actions to encourage students to stay in institutions, such as the Permanence Grant and the Student Funding Fund (FIES), which allows the student to finance part of the monthly tuition not covered by the scholarship program. With the ENEM, other opportunities for access to higher education were implemented, like the FIES, where the Federal Government invests public subsidies in private institutions. Despite the advances in the number of access to colleges and universities, two-way financing can be analyzed: the problem of student debt with public banks, masked by the title of educational investment, and the other part of the principle of values that could be invested in public universities, in a program of valorization of these, which would make it possible for most Brazilians to have direct access to quality Public Higher Education. The theme of the issues, and especially of the essay, aims at dealing with current and contextualized issues that insert the candidate in an applied context, where human rights are valued, integrating knowledge from the various areas of scientific knowledge, in order to allow an interdisciplinary approach and that leads the student / candidate to solve problems of life in society.

However, despite the reorganization and strengthening of the ENEM, brought about by the reformulation of its matrix, when the socio-environmental issues are observed, they are still fragmented and insufficient, since general issues are addressed and do not value the multiplicity of looks and the process of formation of the country, mainly its regionalization, thus favoring specific regions of the country, such as Southeast and South. In this way, it can be questioned whether the exam serves in fact to bring to the discussion the social-environmental problems or to create a school model that seeks results and has its autonomy compromised through the follow-up of its parameters and didactic materials elaborated by educational systems.

The teaching of Environmental Sciences based only on teaching materials can lead to issues such as: the reproduction of cartesian science, insufficient to answer the questions of a dynamic world and the opening of gaps in the citizens' education of the students, compromising the teaching autonomy. In the same way, the school is seen as a mere transmitter of what must be taught in order to attend mercantilist interests, neglecting discussions on topics of interest to the community (BELTRÃO, 2014). Among the hidden topics can mention local environmental problems, since the main objective of con- 
tent education is to develop ENEM reference matrix, which is in the education systems the concrete means content delivery that underlie educational planning.

The contemporary school adopted, through the ENEM, a model of assessment based only on its guidelines and, thus, gives way to collective planning and critical thinking, which considers multiple knowledge, assigning to teachers and students the task of understanding what is required by the examination. Likewise, it is observed that through the adoption of such parameters, the school can become mechanistic and repeat practices that occurred in the old exams that were replaced by ENEM, and only from this, to evaluate their practices, not making room for Integration between internal and external evaluation policies.

The purpose of this study is to discuss the implications of the ENEM for the teaching of Environmental Sciences, with emphasis on the insertion of questions of local scale in High School, in which the discussions about the theme can be carried out in a punctual and discontinuous way, disintegrated of reality and based on instruments such as the textbook or directed to ENEM.

In order to reach the proposed objective, a preliminary collection of bibliographic and documentary data, analogical and digital, was carried out in several sources made available in direct and indirect public administration places, such as theses, dissertations, books, book chapters, published scientific articles in journals in the CAPES database, among other bases, as well as the tests of the ENEM Human Sciences and Natural Sciences, applied in 2016.

Firstly, the areas of Environmental Education (EE) were discussed, encompassing the processes of intellectual formation of the human being as a citizen and the main implications for insertion of the local scale in school discussions. Subsequently, an analysis of the instruments used by those conducting the training and the main pedagogical challenges to be overcome in the search for alternative paths for the training of participatory subjects was carried out.

\section{THE TEACHING OF ENVIRONMENTALSCIENCES AND THE PEDAGOGICAL CHALLEN- GES IMPOSED BY THE NATIONAL HIGH SCHOOL EXAMINATION}

\section{Distinct AREAS OF ENVIRONMENTAL EDUCATION}

EE can be recognized in two spheres: the formal and the non-formal. The first is developed in the curricular proposals of the school disciplines, being essential that it be approached in a continuous and interdisciplinary way, enabling the critical and reflective formation of the students, sensitizing them about the current socio-environmental crisis and the role of humanity on this phenomenon, as well as motivate them to make decisions regarding the needs of future generations. On the other hand, non-formal EE encompasses spaces that go beyond the college borders, involving and bringing to the discussion the various component individuals of the communities, who integrate and belong to certain places, and must seek integration between the school and various sectors of society (REIS; SEMÊDO; GOMES, 2012).

While man is taught to act according to the current social model, from the socio-environmental point of view, the interaction with natural systems is given by the form of resource. Nature is seen as supply, means of extraction and infinite object, something that has been given to them to be enjoyed and, through this thought, the beginning of environmental degradation is visualized, not only packed by the uncontrolled withdrawal of its components, but mainly by the Process of acculturation of those who act like this.

The school, through its essential role in human development, the nature of its creation as a social construction, has function to keep the current capitalist system. Despite growing concern about environmental degradation, it ends up reproducing and disseminating negative anthropogenic practices with nature, which may be related to the lack of improvement of its teaching staff. However, the school is not to blame for this degradation, considering this space as a social construct and, therefore, an ideological apparatus of the State. Also, it should not be judged that all socio-environmental problems can be solved totally in school, but rather that they can be reflected and discussed, stimulating the sensibility and subsequent decision making. 
The environmental knowledge 1 amounts as proposed participatory integration, not treating the environment by branches of naturalist Ecology, led by the essences of purely natural environment, biotic factors as beings interacting with abiotic, but the perception of this as a whole, Its complexity, which encompasses both the natural relations described here and also encompasses human relations: social, economic, historical and cultural, and the ways in which they influence environmental systems, thus building new realities.

The importance of school actions in relation to EE in a critical and emancipatory way permeates several stages, ranging from the discussion of social paradigms that support the creation of school as a mean of reproduction of the capitalist system, as well as the need to discuss small actions and the critical awakening of individualities as an integral part of an environment endowed with cultural and historical values, meanings and representations, that needs to awake the "being" nature to the detriment of "having" nature, valuing the feeling of belonging, so as to encompass its place.

Although education for the environment in the school space is built as essential for critical, conscious and emancipatory development, this statement, widely used in school actions, is translated as punctual activities, discontinuous and disintegrated projects. When performed, they are made as a disciplinary obligation, in a reduced space of time, presented only as a cross-cutting theme, when approached in the disciplines that best resemble them, and not as motivating themes and generators of discussions that cover all the educational units and that is present in the wake of socio-environmental issues, mainly of a local nature.

The insufficient comprehension of the actions of EE in Basic Education, based on secondary education, is done by the restricted follow-up of teaching instruments such as the National Textbook Program (NTP) and ENEM guidelines, which select candidates for access to Higher Education. Despite the increasing advances that are brought by the two government programs, of which only the ENEM was the focus of this study, the idea of global environmental discussion can be interpreted as an implication / barrier to the development of environmental actions at local level, hiding the place in the School syllabus.

\section{THINKING AND ACTING LOCALLY: ENEM'S PEDAGOGICAL AND INSTRUMENTAL CHALLENGES}

In Brazil, the decoupling of the local reality of school subjects, mainly the content required by ENEM, which bring up issues such as the environmental impacts caused by human action, but without a full discussion of the case, giving mechanical character and not critical what the student lives and sometimes causes low understanding and disconnection of the cultural values of this, making the content abstract and difficult to understand, making the space destined to emerging manifestations in the different educational spaces is restricted (BELTRÃO, 2014).

The politics of the exam can be viewed from positive and negative points in relation to traditional test: on one hand, the evolution occurred in form of the approach of the questions - more contextualized with the several areas of knowledge, opening space for interdisciplinary discussions - On the other hand, the national scope of the contents of the test made that the particularities of each vestibular were lost and the questions focused on the regional and/or local characteristics. In addition to what was discussed previously, some issues may prioritize specific regions of the country, such as the Southeast and South regions, as well as addressing disjointed situations with what actually happens.

As Gusmão (2016) teaches, in order for the effectiveness of the teaching of Geography, Biology and other Environmental Sciences to be convincing in the conscious formation of the student about the reality circumscribed in the space in which he lives, it is essential that the teacher leads him (the student) to reach the spatial understanding that goes from a local / global scale, and finally arrives at the greater understanding that is the "your reality." Still according to the same author, the analysis of the reality materialized in the geographical space needs to be fulfilled and, especially in High School, segment in which there are more mature possibilities of dialogue, this objective must be met.

Many things has been said in education for citizenship, but in a way that is often unrealistic and unreachable, bureaucratic, linked to positivism and with technical solutions, defined in one or several objectives that, more often than not, consider the subject - the student, displaced in the world,

1 According to Leff (2009), the environmental knowledge problematizes the knowledge that has been fragmented in disciplines in the scope of forming a new field of knowledge that rearticulate the relation society-nature, distanced by the scientific development. For this, transdisciplinary processes are used that go beyond Environmental Sciences, problematizing and transforming dominant paradigms, in the search for (re) totalization and internalization of this new knowledge. 
in which he lives as if he were a neutral and abstract being (CALLAI, 1996).

The logic of the ENEM, NTP and private education systems, which mostly follow the formatting required by the first, direct students to a market formation and, especially, more elite courses, can be defended as an unfounded attempt to encompass general characteristics and that disregard the process of formation of the Brazilian people, neglecting the regional differences, assuming that, in this way, the candidates for a place in Higher Education will become critical, reflective and with an expanded worldview. Thus, the knowledge defended by the exam arises superficially in the evaluation, requiring only concepts or decision making to solve questions, losing space to the practical approach and the resolution of real problems that the students face daily.

As an example, when analyzing the ENEM 2016 test, more precisely the 3 - blank notebook, applied on the first day of the test, from the 45 questions in the block "Human Sciences and their Technologies", 14 presented some content specific to Geographical Science and, only 05 questions brought up an environmental debate, as can be seen in Table 01.

Table 01 - Analysis of the questions of Human Sciences and their Technologies (ENEM 2016)

\begin{tabular}{c|c|c}
\hline Question & Content & Scale \\
\hline 16 & Brazilian Cerrado & National \\
\hline 18 & Desalination of water & Global \\
\hline 22 & Brazilian Natural Environment \\
\hline 28 & $\begin{array}{c}\text { Industrial fishing and destruction } \\
\text { in Africa }\end{array}$ & Global \\
\hline 35 & $\begin{array}{c}\text { Kyoto Conference and CO2 } \\
\text { emission }\end{array}$ & Global \\
\hline
\end{tabular}

Source: inep.gov.br (2017)

Similarly, when analyzing the block of Natural Sciences and their Technologies, of the 45 questions proposed, only eight signaled the environmental theme. However, among these 45 questions, only six actually were in the field of the Environmental Sciences because they provided an initial view of the interactions between the different systems. Other questions considered topics related to the environment, but they did so in an isolated and superficial way and were therefore not considered for analysis, since they did not mention the interactions of the organism/phenomenon addressed in ecosystems, valuing dissociative teaching, which does not appreciate interactions socio-environmental, contradicting the exam's own proposal and the concept of interdisciplinarity.

Table 02 provides a detailed explanation of the selected issues and the content with which they interact and their approach on a global/national scale.

Table 02 - Analysis of the questions of Natural Sciences and their Technologies (ENEM 2016)

\begin{tabular}{c|c|c}
\hline Questions & Content & Scale \\
\hline 57 & Climate Changes & Global \\
\hline 62 & $\begin{array}{c}\text { Emission } \text { of } 2 \text { and Nutritional } \\
\text { Quality }\end{array}$ & Global \\
\hline 64 & Brazilian Biomes & National \\
\hline 66 & Agroforestry Systems & National \\
\hline 76 & Food Webs & Global \\
\hline 90 & Bio-digesters & Global \\
\hline
\end{tabular}

Source: inep.gov.br (2017) 
The integration between the disciplines of the block of Natural Sciences and environmental questions, here understood as a transversal theme / motivator, is much more observed in the disciplines of Biology and Chemistry, since only one issue of the selected ones can integrate the content worked In the discipline of Physics, which can highlight the common difficulty of inserting interdisciplinary topics in the disciplines of the area of exact, even this composing the Sciences of Nature. According to Miranda and collaborators (2011), the contextualization of student knowledge has been reformulated in an ambivalent and antagonistic way, in an attempt to harmonize discourses, valuing practices beyond the criticality necessary for the Education of the future.

The idea of universalization about what must be taught lies in topics such as: terrestrial biomes, global warming, greenhouse effect, deforestation, erosion and other contents developed in specific disciplines, in a disjointed and not very participative way, taking the student to exhaustive knowledge of most of the processes conveyed and mainly discussed by the media, but little that covers their reality. As shown in Tables 01 and 02, students are able to discuss the effects at a global level, but little related to historical-cultural processes at the local level. It is taught to think how the system requires or to pass examinations that tell the world that they have learned what it was necessary to learn. But, learn for what? Learn what?

As Sousa (2003, p. 183) states: "ENEM presents itself with a greater potential to condition school syllabus, that is, it is taught to obtain good exam results. Students also claim that the ENEM certification policy contributed to teacher devaluation, because students' interest interferes with the way the teacher organizes and elaborates his/her pedagogical practice based on ENEM's proposal (SILVA, 2016).

The ENEM disqualifies and devalues education by determining that schooling knowledge must attend to the needs of the moment, which need to be taught and learned as useful for something. The exam is getting to a type of Education committed to excellence results that reflect the makeup of a successful achievement in life. In view of this, it is observed that the teaching work has been governed by a process of self-intensification, since teachers feel responsible for the success of students in the ENEM, since this evaluation has been configured as an indicator of quality parameters of education (SILVA, 2016).

How will be the (re)construction movement of pedagogical practices when the school and its faculty have their autonomy limited to the abilities and competences of the ENEM or to the concept of school of results? Presented from the outset as innovative and contextualized, the ENEM test model tends to impact didactic materials - even though a good part of these materials are mere compilation of exams already done - but mainly, to indicate some ways and criteria for teaching (BORNATTO, 2013).

According to Gonçalves (2014), comprehension and understanding of this type of assessment become crucial, especially for teachers, from that moment to be the basis for the actions of public policies in education, start to determine, directly and indirectly, the syllabus to be taught, the hours of the disciplines and, finally, the profile of the students who enter the universities.

In EE, the motto "global thinking and local action" is spoken as a deductive justification for valuing local actions with the projection of benefits to the world society. This need for justification in projects may even sound like a disbelief by those who idealize it, when it is observed that a given action only has value when it has an effect on global scales or when the student believes that he is assisting traditional peoples or entire ecosystems beyond their reach in detriment of actions in their environment or for their community. Therefore, the acts made in EE are practiced and seen only through images of books or during classes of specific disciplines of their formation, based strictly on the school curriculum, not composing the objective reality of Education: the construction of the local citizen, being formed the citizen of the World, not its place.

The attitudes mentioned in the previous paragraph can be realized without the perception by the one who takes the lead of the project or action, as already discussed, by the simple question of the environmental training that he received: disjointed and not very participatory. However, it expands profoundly on the need for elaboration of topics that are worked around the world, configuring the local reality as something secondary or irrelevant. Thus, teaching is focused on what is present in the assessments (both content and subjects), leaving the rest forgotten or in the background. 


\section{FINAL CONSIDERATIONS}

The formation of people regarding their posture and relationship with the environment runs through various barriers ranging from their teachings as men and women, social beings, to that which is built through social relationships in their specific settings, such as school. In no other way, the conceptions about the environment, whether viewed as a natural environment isolated or endowed with cultural, economic and social interactions, as a resource or essence, find in the school environment a space to discuss, reflect and shape paradigms for such manifestations are proposed in a critical, reflexive and emancipatory way.

Although the ENEM has brought new proposals to Basic Education, leading to the discussion about the capacity of the student (skills and abilities) as a global citizen and modifier of the environment, in thinking and reflecting on socio-environmental problems, it is insufficient and dissociated from the local reality. While it excludes the characteristics of the different regions of the country, its formation processes and different environmental systems, the examination benefits the appropriation of universal concepts to the detriment of the historical, cultural and social values of the students and emphasizes values of the more developed and industrialized region from the country. Such facts make the school restricts itself to its matrix, leaving aside the originality, needs and demands of the communities to which it integrates, as well as the teaching autonomy.

The school, which previously had difficulties in developing continuous actions of EE with teachers in the course of their disciplines, now is experiencing a gap between what needs to be learned for effective decision-making in the face of local problems and what should be taught to that students are not harmed when performing ENEM. However, the good deeds practiced in the school environment - and beyond its walls - can and should be built on a daily basis through integrative projects that cover the daily life of the most remote localities of their conviviality, so that the scale grows larger.

Thus, through the characteristic the saying "global thinking and local action", the most appropriate for interdisciplinary actions and that promote the holistic formation of the learner as a critical and reflexive citizen is that an EE be conceived in a context of integration of scales, valuing the formation of the citizen of the place, taking into account the values of those who live daily at school and, corroborating with this, to critically visualize the didactic instruments that dictate the teaching and student postures and the way social-environmental concepts are discussed.

\section{REFERENCES}

BELTRÃO, J.A. A Educação Física na escola do vestibular: as possíveis implicações do ENEM. Movimento, v. 20, n. 2 , p. 819-840, 2014.

BORNATTO, S. P. A redação do ENEM e a formação docente. In: National Congress of Education [Internet]; 2013 September 23-26; Curitiba, Brazil. 2013 [cited 2017 Feb. 22]. Available from: http://educere.bruc. com.br/ANAIS2013/pdf/9981_7059.pdf

BRAZIL. National Institute of Educational Studies and Research Anísio Teixeira. Ordinance ${ }^{\circ}$ 438, of May 28, 1998. Institutes the National High School Examination - ENEM. Brasília (DF): 1998.

GONÇALVES-JÚNIOR, W.P.; BARROSO, M. F. As questões de Física e o desempenho dos estudantes no ENEM. Revista Brasileira de Ensino de Física. v. 36, n. 1, 2014.

GUSMÃO, A.D.F. Os prismas da Geografia no exame nacional do ensino médio (ENEM): abordagem conceitual e temática da ciência geográfica na avaliação de 2015. In: National Meeting of Geographers [Internet]; 2016 June 24-30; São Luís, Brazil. 2016. [cited 2017 Feb. 22]. Available from: http://www.eng2016.agb.org. br/resources/anais/7/1466861452_ARQUIVO_OsPrismasdaGeografianoExameNacionaldoEnsinoMedio(E NEM)-abordagemconceitualetematicadacienciageograficanaavaliacaode2015.pdf 
LEFF, E. Complexidade, Racionalidade Ambiental e Diálogo de Saberes. Educação e Realidade, v. 34, n. 3, p. $17-24,2009$.

LEFF, E. Saber ambiental: sustentabilidade, racionalidade, complexidade, poder. 7. ed. Petrópolis: Vozes, 2009.

MIRANDA, E.M. et al. ENEM 2009: articulações entre CTS, interdisciplinaridade e contextualização evidenciadas nas questões de Ciências da Natureza. In: National Meeting of Research in Education in Sciences [Internet]; 2011 December 5-9; Campinas, Brazil. 2011. [cited 2017 Feb. 22]. Available from: http://www. nutes.ufrj.br/abrapec/viiienpec/resumos/R0292-1.pdf

REIS, L.C.L.; SEMÊDO, L.T.A.S.; GOMES, R.C. Conscientização Ambiental: da Educação formal a não formal. Revista Fluminense de Extensão Universitária, v. 2, n. 1, p. 47-60, 2012.

SILVA, S.G. ENEM: implicações no currículo e no trabalho docente em educação de jovens e adultos. In: ANPED Regional Scientific Meeting [Internet]; 2016 July 24-27; Curitiba, Brazil. 2016. [cited 2017 Feb. 22]. Available from: http://www.anpedsul2016.ufpr.br/wp-content/uploads/2015/11/eixo13_SIMONE-GON\%C3\%87ALVES-DA-SILVA.pdf

SOUSA, S. Possíveis impactos das políticas de avaliação no currículo escolar. Cadernos de Pesquisa, n. 119, p. 175-190, 2003. 